\title{
Reading 'Pterodactyl, Puran Sahay, and Pirtha' amongst the Barabaig Tribe of Eastern Tanzania
}

\author{
Mary Louisa Cappelli \\ MFA, JD, PhD, Nevada State College. Orchid: oooo-0oo2-0419-9411. \\ Email: Mary.Cappelli@nsc.edu
}

First published July 12, 2019

\begin{abstract}
:
The Barabaig peoples are vulnerable economic and ecological refugees pushed to the furthest corner of the Bosutu Plains of Eastern Tanzania to eke out a subsistence existence amidst encroaching capital and globalizing forces. In many ways, the Barabaig face struggles similar to those encountered by the tribals in Mahasweta Devi's "Pterodactyl, Puran Sahay, and Pirtha." In this essay, I offer my own ethnographic research to survey the anguish of the Barabaig peoples who try to hold onto their cultural traditions and ways of life in a world geared towards globalized progress. In so doing, I demonstrate how the construction of tribal songs and mythohistories challenge global dynamics and renegotiate gendered positions within dominantly indigenous patriarchal contested spaces. These powerful stories and songs reflect how indigenous mothers imagine and control their own gendered history and preserve their cultural identity and traditional livelihood.
\end{abstract}

Keywords: Mahasweta Devi, 'Pterodactyl, Puran Sahay, Pirtha,' Mythohistories; indigenous peoples; tribals, Mahasweta Devi; Tanzania; Barabaig; indigenous resistance; environmental sustainability; indigenous story telling, indigenous songs, animism, Gayatri Spivak.

\section{Introduction}

In Imaginary Maps, Mahasweta Devi (1994) writes, "The tribals want to stay in the place which they know as their own" (p. xxii). She also writes: "Whatever has come in the name of development has spelled disaster for the tribes" (Devi, 1994 p. xxii). This is equally true for the Barabaig Peoples of Eastern Tanzania who strive to maintain their subsistence livelihoods despite policies and "arrangements for extinction" (Devi, 1994, p. 170). In Unbowed: A Memoir, Wangari Maathai (2007) argues that the "future of the planet concerns all of us, and all of us should do what we can to protect it" because if education means anything, it should instill in humanity the respect for the land, "because educated people are in the position to understand what is being lost" (p. 137). Teresa Leal, Cochair (2002) of the Southwest Network for Environmental Justice, said, "We must throw rocks at the sun" to challenge and resist globalizing forces; and, in Africa, the essentials of life seem more intense, issues of water and food security more demanding (qtd. in Adamson, Evans, \& Stein, p. 13). Guided by the whispering of their ancestors and the anima mundi (soul of the earth) of the Bosuto Plains, the Barabaig throws rocks at the unrestrained "development" projects that have devoured their people, their land and their resources without mercy.

(c) AesthetixMS 2019. This Open Access article is published under a Creative Commons Attribution Non-Commercial 4.0 International License (http://creativecommons.org/licenses/by-nc/4.o/), which permits non-commercial re-use, distribution, and reproduction in any medium, provided the original work is properly cited. For citation use the DOI. For commercial re-use, please contact editor@rupkatha.com. 
It is my contention that the Bosuto Plains provides an urgent place-based site for the analysis of indigenous resistance to land displacement, globalization, and environmental degradation. Since April of 2011, I have been fascinated as to how the Barabaig-strong sentient beings-have been able to sustain themselves against what Vandana Shiva (2005) refers to as capital's "creation boundary" of patenting, land-enclosures, and population control policies aimed at subaltern and indigenous peoples and livelihoods. This fascination led to an oral history and participatory action research project to examine the influential mythohistories in the construction of cultural beliefs and ideologies surrounding reproduction. Synthesizing the notion of indigenous ecoconsciousness as the mindful other of globalization, this essay hopes to offer an indigenous model for re-visioning relationships between humanity and nature. Like Puran in Pirtha, I went to the Bosuto Plains "having read many books and done a lot of homework" (Devi, 1995, p. 183). My research methodology engaged "the why and the how," drawing on several sources ranging from fieldwork, personal interviews, videography, telephone interviews, extensive legal research, and analysis of historical documentation (Devi, 1995, p. 143). ${ }^{\mathrm{i}}$

It was on my first visit to the Bosuto Plains that I was introduced to Mahasweta Devi as part of my competency exams for my PhD. I brought a copy of Mahasweta Devi's Imaginary Maps with me to read. And, yes, I was immediately struck by how the struggles facing the Barabaig community are similar to the plight of the Adavasi. Both live in the "primordial dusk" and when "invaded," "crawled" deeper and deeper into earth's womb for safety (Devi, 1995, p. 109). Their "land vanished like dust before a storm," and their homes and fields "all disappeared" (Devi, 1995, p.119).

I am also aware of my own shortcomings as a researcher and what Trinh T. Minh-ha (2009) refers to as the limitations of an "analytically trained mind" (p. 141). Is it possible that in the "recording, gathering, sorting, and synthesizing" of these discourses that I have not somehow imposed my own "dualistic structure" and second wave feminist values in my research (p. 141). Similar to Devi's Puran, I accept the inability of language to convey meaning and representation and the "im"possibility to truly understand the discourses I have recorded as "objects" of study and analysis. I am also aware that these mythohistories and songs are not immutable as they are affected by the changing socio-political and environmental forces that continuously affect dailylived conditions and by (me) the ethnographer who records, transcribes, and analyzes them.

Nonetheless, mythohistories are valuable discursive sites for the examination of reproductive resistance and tribal sustainability to show how "traditional peoples developed rituals and practices that maintain(ed) their populations in a balance with local resources" (Merchant, 2005, p. 211). For centuries, mythohistories and songs have been powerful discourses in the maintenance of Barabaig collective tribal identity and female consciousness. Through the collective acts of "speaking, listening," and "procreating," women engage in the processes of retrieval and revival of Barabaig cosmologies of cultural origin (Minh-ha, 2009, p. 126). Analysis of the myths and songs about female reproductive livelihoods and procreation demonstrate the importance of women's labor in Barabaig tribal sustainability, enabling readers to listen and bear witness to the junctures and dis-junctures of women's lives. These narratives reaffirm relationships and connect the Barabaig to their land and community showing future generations how to live and respect their culture and their traditional connection to the earth. Simultaneously linear and cyclical they incorporate elements of social life and history in which cultural affectations are transferred and act to inaugurate women's motherhood position in the social relations of tribal reproduction. In this essay, I offer my own ethnographic research to survey the anguish of the Barabaig peoples who try to hold onto their cultural traditions and ways of life. Employing Tuhiwai Smith's (1999) decolonizing methodologies of "local theoretical positioning," and previous models of 
ethnographic listening, I examine the reproductive terrain of Barabaig women and influential mythohistories in the construction of cultural beliefs and ideologies surrounding reproduction (Smith, p. 186).



Figure 1. Barabaig women of the Bosuto Plains dressed in traditional dress.

\section{Historical Perspective}

In 1955, while conducting research amongst the Barabaig, George Klima (1970) predicted that the tribe would ultimately evolve from a semi-nomadic herding culture to a "sedentary horticulture" (p. vii). At this juncture, the Tanzania Government was attempting to absorb its indigenous peoples into its national system and in a 1968 edict, "banned the wearing of the traditional redochred toga" (Klima, 1970, p. vii). Yet, My time spent amongst the Barabaig women of the Bosutu Plains proves Klima's prediction inaccurate. The Barabaig women have carved out a pocket of indigenous resistance and are a living testimony to a strong spirit of survival. Men and women still wear their traditional clothing and the government restriction to ban the wearing of the red toga has done little to restrict cultural traditions. What the Government did not take into account is the strong macro-religious significance given to traditional cultural and socio-economic practices and mythohistories. Young Barabaig mothers still practice facial stratification and distended ear-lobes, wear colorful beaded strings in geometric patterns and elaborate neck coils. The majority of households still practice polygamy and cattle herding is still one of the major means of subsistence and cultural and existential focus. Cattle are not only needed for biological survival, but also serve to confer social and personal position within society.

The "transformative change" Klima described over half a century ago has been in actuality a dynamic process of cultural and ecological resistance against globalizing forces. In fact, since the 1990s the Barabaig have been able to maintain a modified degree of cultural integrity and both social and environmental sustainability. This is true in spite of the restructuring of sociogeographic areas in the interest of globalization and the jurisprudent land policies of privatization 
and villagization, which have systematically suspended constitutional rights and legal protections. The powerful infiltration of neoliberal forces culminating in land and resource grabbing over the last four decades has fashioned a geographical landscape of displaced indigenous peoples struggling to restructure their lives in inhabitable terrain, which for the most part struggles to support life forms. Mahasweta Devi's (1995) observation examining "the wheels of progress" and comparing ancient civilizations with modern progress is valid. "Modern progress is much more barbaric at heart" as it slowly destroys a "continent in the name of civilization" (p. 195).

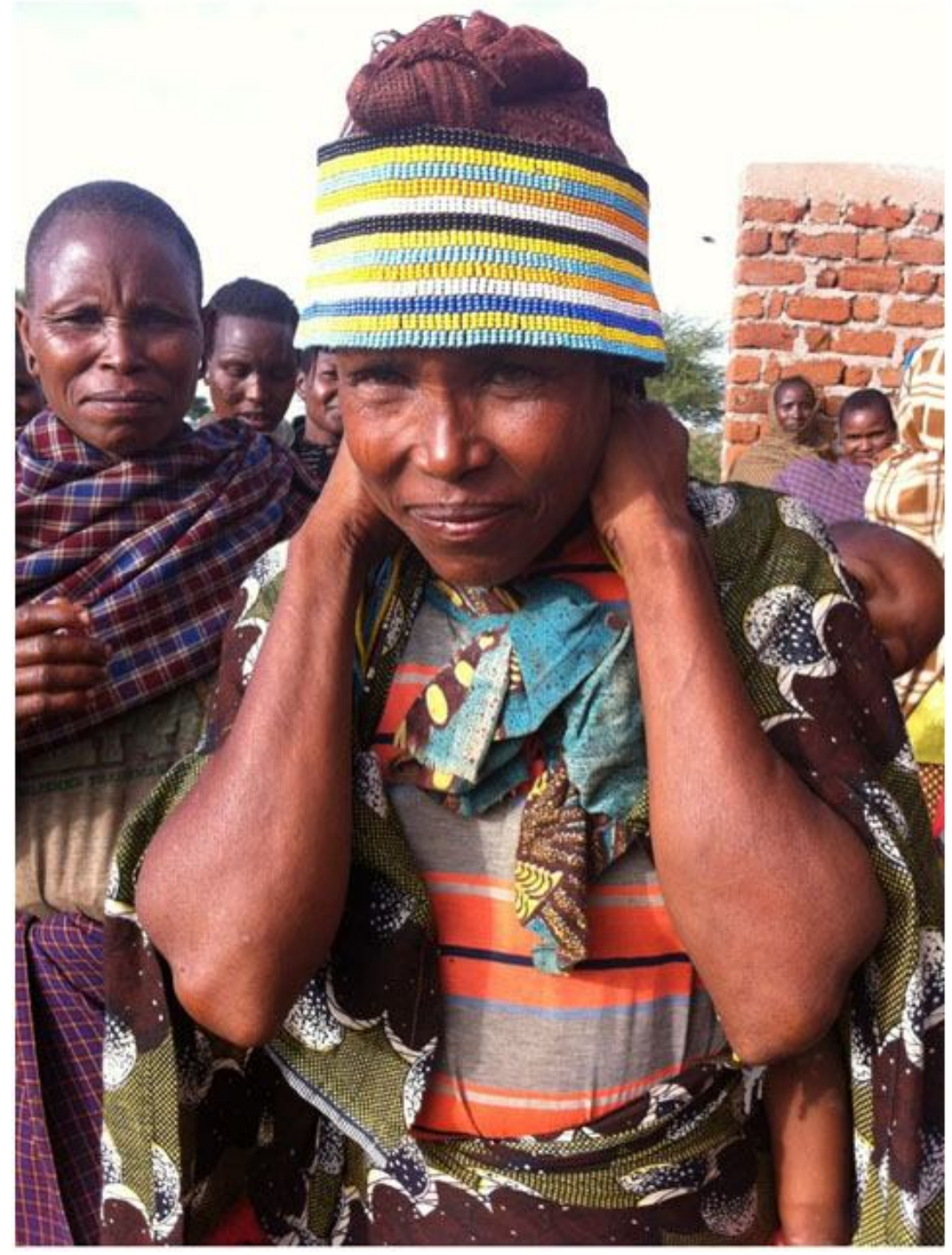

Figure 2. Mother with Facial stratification

International business conglomerates acting in collaboration with the economic interests of the Tanzania's nation state, is evidenced in the 1960 decision to cultivate wheat in the Arusha Region of the Hanang District. The United Republic of Tanzania along with the Canadian Food Aid Programme launched the Basotu Wheat Complex securing ten thousand acres of Barabaig land for wheat farming. In 1970, the National Agriculture and Food Corporation (NAFCO) expanded the project developing several large scale wheat farms securing 120,000 hectares of Barabaig pasture land, including homesteads, water sources, sacred burial grounds, and wild life. Like many other indigenous tribes, the globalization's one-way road came "chasing them" as their 
livelihoods "disappear(ed) making the four corners unclean" as progress trampled over their ancestral graves (Devi, 1995, p. 120).

Sadly, many Barabaig were unaware of the legal maneuvering for their land and first found out about it when tractors ploughed through their homesteads. According to reports and interviews, NAFCO failed to give due process to people living on their land at the time and were deemed to be trespassers on their own property. "We were forced off our own land by gunpoint," recollected one of the elder mothers (M. Cappelli, personal interview June, 2012.) Another Barabaig narrates how he was jostled from sleep and displaced:

It was 19th February 1985 around 1.00 p.m. I was returning from watering my cattle. A NAFCO Landover from the direction of Kate's town pulled up beside me. Mwaigul, NAFCO's Assistant Manager, was seated in the front seat beside the driver. In the back, there were four armed Field Force Unit (FFU) soldiers and a plainclothesman. Mzee Duncan was also in the vehicle. Mwaigul pointed me out. The soldiers threateningly ordered me to board the vehicle. I had no guts to ask questions ... At Waret, the vehicle was driven around the houses of NAFCO managers and white expatriates. More beer was served to the soldiers. The day was wet and chilly as it had rained heavily that day.

It was late in the evening.

'Masikio!' (ears) called out one of the soldiers referring to me on account of my pierced ears. At gunpoint I was ordered to lie down in a ditch and roll in the mud. I began to shiver. Jonas, the Chairman, was called 'Chairman of Wamang'ati' [a derogatory reference to Datooga people]. He was also ordered to roll in the mud. Meanwhile women and children from the surrounding houses were watching us and NAFCO staff seemed to be amused and happy. (Shivji, 2007)

In the 1981 Case of National Agricultural and Food Corporation v. Mulbadaw Village Council and Others, the Barabaig sought legal protection and sued the National Agricultural and Food Corporation (NAFCO) for trespass on their land at the High Court of Tanzania in Arusha. While the High Court of Tanzania (D'Souza, Ag. J.) ruled in favor of the Barabaig Plaintiffs, stating that the Barabaig occupied land under customary title, the Court of Appeal of Tanzania overturned the decision and ruled in favor of NAFCO stating that "the Plaintiffs/Respondents - Mulbadaw Village Council did not own the land in dispute or part of it because they did not produce any evidence to the effect of any allocation of the said land in dispute by the District Development Council as required by the Villages and Ujamaa Villages Act of 1975" (Peter, 2007). In effect, the Village Council had trespassed by entering their own traditional lands: The Court of Appeals ruled that the villagers failed to meet the burden of proof that they were natives within the meaning of the law (my emphasis). ${ }^{\text {ii }}$

Legal analysis of case precedence demonstrates that the Tanzanian government discounted Barabaig collective customary rights, discounted Barabaig tripartite land holding practices, ignored detrimental ecological effects derived from the alienation of pastoral lands, and moreover privileged the privatization and commodification of land and foreign and national interests over local indigenous rights. Vandana Shiva's (2010) global observation of indigenous dispossession holds sadly true for the Barabaig as "village after village is being robbed of its lifeline, its sources of drinking water, and the number of villages facing water famine is in direct proportion to the number of 'schemes' implemented by government agencies to develop water" (p. 171). Political power backed by powerful interest groups proved in this case study that civil law is not the same as global power, and that in the vulnerable world of "nation-states," placelessness and 
dispossession is a political consequence of globalization. Devi (1995) says it best:

The truths and the lies are the same

The truth, the tribal receiver gets nothing.

The lie, the government's proclamations are only on paper,

they do nothing when it comes to reality. (p.192)

While the Barabaig have retained many of their traditional practices, the plains continue to be a dynamic contested space for the exploitation of resources creating a complicated dialectical tension between local people and regional, national, and international spheres of interest; Barabaig mothers continue to face severe threats to their society and environment, and struggle daily to subsist. Enclosure of common herding lands for Sino-African infrastructure development projects, private farming, private ranches, and conservation wild life parks have placed undue hardship on the Barabaig's ecological environment and its ecosystems. These external forces coupled with their traditional creation myths and songs have rendered women exceptionally vulnerable to the intersecting forces of traditional patriarchy and capitalist patriarchy. Before I begin, I must mention that Chief Daniel, the chief of the subdivision, had converted to Christianity and since has chosen the youngest of his five wives to live with, while relinquishing all marriage duties to his other four wives who now suffer from food and water insecurity. ${ }^{\text {iii }}$ The four women are part of the 25 widows with whom I worked and who suffered from the imposition of our "rotten value system," where the outcast women are forced to suffer kinship displacement (Devi, 1995, p. 118).

Also important to understand in this patrilineal kinship system is the practice of dugbadaiddowry cattle-which still plays a significant role in marriage unions. In dugbadaid, the bride's family gives from 2 to 40 heads of cattle to the daughter, which "will be kept in truth and later redistributed to her sons as marriage and inheritance cattle and as dowry for her daughters" (Klima, 1985, p. 10). A woman cannot remarry once she has a son and "the dowry she brings to the marriage will not be returned" (Klima, 1985, p. 9). In 1964, Klima (1985) writes that "the legal status of Barabaig women is reflected in the jural institution of girgwagedgademg a 'council of women'," who gather "to deliberate as a judicial body, adjudicate and enforce their rights, and to impose legal sanctions against men" (p. 12). The council of women is authorized by myth and realized by community support and action (Klima, 1985, p. 12). While working with the Barabaig, I participated in girgwagedademg-always with men present who inserted their own personal requests and opinions. For example, although the chief condoned participatory action in working with the widows to identify a subsistence strategy for feeding themselves and their children, he too requested similar relief. Thus, in exchange for participating in the acquisition of seeds and goats for the mothers, the Chief desired the same along with an additional request of a cell phone. Similar to Devi's (1990) "Strange Children," I have observed layers of patriarchal corruption in many relief-giving processes-in which relief seldom fully and adequately reaches the most vulnerable-the women who are caught in between the complicated and often violent global intersection of traditional patriarchy and capitalist patriarchy. In Susan Hawthorne's (2009) essay, "The Diversity Matrix: Relationship and Complexity," she recognizes the complexity of intersecting economic structures (p. 87). These are the similar crisscrossing structures in which the Barabaig presently live as their lives and interactions indeed "takes place across a number of different social worlds," as they negotiate daily between the interaction of social, political, and natural worlds-all vying for scarce resources (Hawthorne, 2009. p. 87). Within this complex framework, the Barabaig's central focus is subsistence and maintenance of their existing 
traditional livelihoods. It is for this reason that in my analysis of their songs and mythohistories on reproduction, I apply a theory of complexity economics that recognizes the "interacting relational systems" and "intergenerational sustainability of economic systems" (Hawthorne, 2009. p. 88).

\section{Mythohistories}

The first creation myth I present functions as a "personal myth" for understanding Barabaig collective history and the interrelationships between Datooga Tribes. ${ }^{\text {iv }}$ In this myth Chief Baba narrates the story of the first Barabaig descendent:

There was a Barabaig named Sedoyeka who was ugly and had a hard time attracting women, yet he wanted to marry. He looked everywhere, but women weren't attracted to him. Sedoyeka was rejected by every women he wanted to marry. He was a wizard with special powers. Sedoyeka went to a house owned by Ombayega, who is believed to be the first Barabaig. Ombayega had a beautiful daughter with deep rich eyes and skin the color of honey. She was the most beautiful girl in the village. Ombayega's daughter refuses to marry Sedoyeka. Sadoyeka tells Ombayega's daughter, 'If you don't marry me, I will make you blind!'

The daughter refuses. Then Sedoyeka blinded the girl.

Sedokeya said, 'If you accept to be married you will see again, and if you don't you will never see again.'

The girl accepts his hand in marriage and receives her vision and is able to once again see.

Sedoyeka's power to make people blind is unknown. One day, after the daughter went to live with Sedoyeka, Ombayega's donkey disappeared.

Ombayega was upset about the loss of his donkey and went out to search for it. He searched and searched everywhere in the forest, in the hills, in the grasses. He searched and searched never to return. Today, the Barabaig still wait for Ombayega's return as the owner of the original Barabaig home.

Datooga is the original and general name of many tribes including the Barabaig, Gisamjanga, Bajuta, and many others; however, Ombayega was the founder and the Barabaig and all Datooga Tribes are all descendants of the Ombayega.

In this creation story, the establishment of the founding father is reinforced along with the tracing of patrilineal descent to establish Barabaig clan identity. This occurs "through a long line of male connecting links starting with the after and up to the father's father, to the father's father's father and so on until the founding father is reached"-all which, requires "memorization and retention" (Klima, 1985, p. 39). The telling and retelling of the story reinforces the generation rule of the father; albeit, it appears that Klima was correct in his assertion that over time and historical conditions, memory has become distorted. Similar to the tribals in Puran, these important creation stories "are also getting lost, they are losing their way, like motes in the face of a dust storm, ancient tales, history, songs, sagas, folklore folkways" (Devi, 1995, p. 186).

In addition to determining the rule of the father, we also witness the punishment of women who refuse to obey. In this story, Ombayega's daughter is punished with blindness for her initial 
refusal to marry Sedoyeka. It is only after the daughter acquiesces to Sedoyeka's hand in marriage that her physical sight is restored. The integration of female punishment for daring to refuse an offer in marriage into the narration of the first Barabaig descendent reveals a deep-structural mythopoetic function in which the narration collectively unites members of the Datooga tribes and at the same time reinforces women's reproductive position within its social systems. Moreover, the narration reveals a male reproductive consciousness in which sexual desires appear to be the "prerogatives of the male species" (O'Brien, 1983, p. 4).

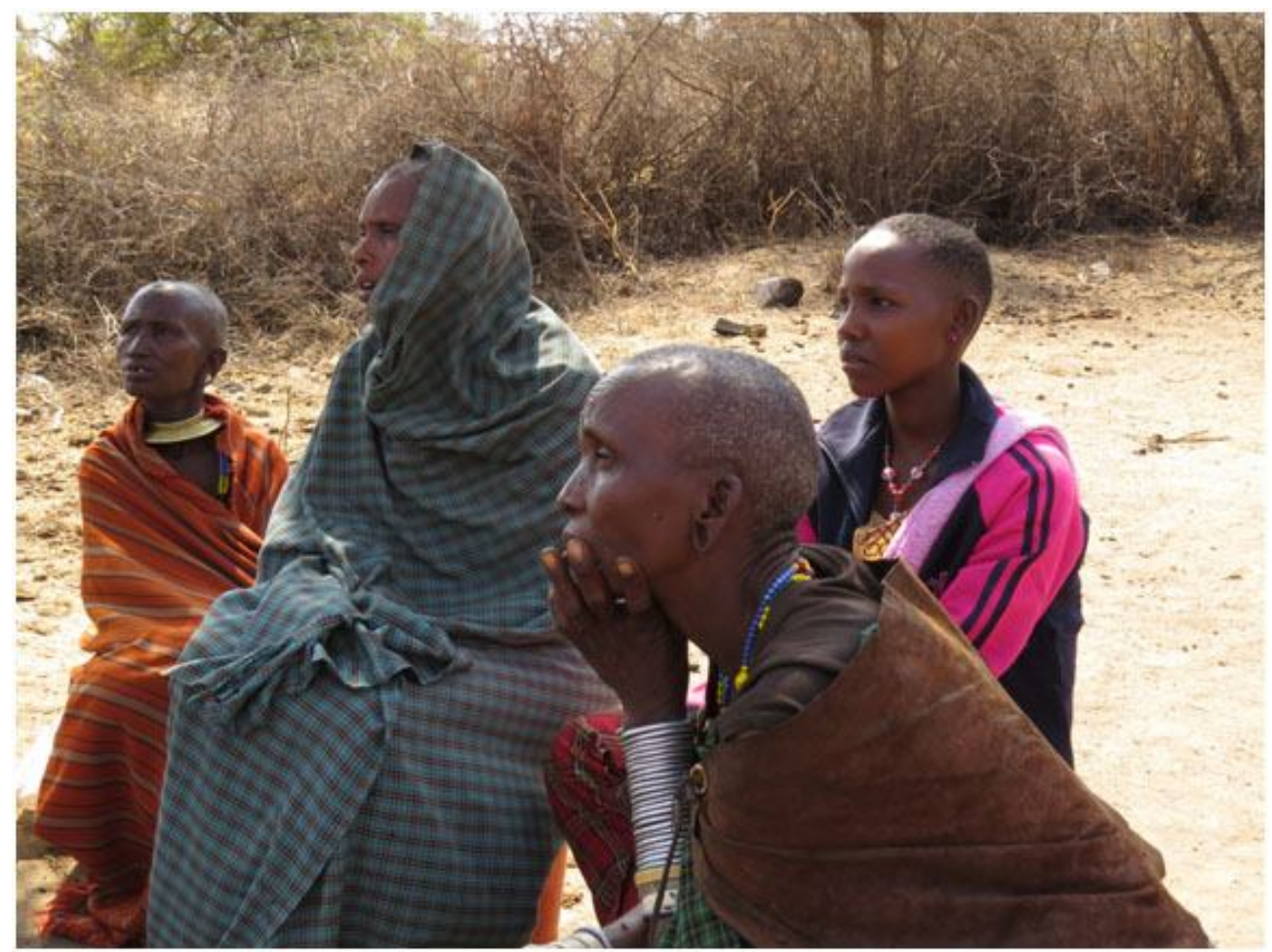

Figure 3. Mothers gathering to sing

According to the Tribal Chief Daniel, the "leaders made laws, taboos, and commandments taught in oral stories to teach the community how to live. If these rules are broken, it is a considered a sin, and they will be punished by ancestors," as in the blinding of nonconforming women. Disciplinary punishment is distinguished at its most primal level in terms of a male/female binary in which male desires are privileged. In addition to framing an epistemological direction, these creation myths explain the world, guide social kinship relations, and address spiritual yearnings, providing collective meaning and solidarity to the tribal members (Kupperman, 2010, 186). The myths and songs, moreover, enable the members to understand and reconcile their historical position in their mythologized community against a vastly changing globalized environment where international interests now vie for their land and resources. The waiting for "Ombayega's return as the owner of the original Barabaig home" reinforces the ancestral and legal customary ownership of these lands - although they have been challenged in court.

Placing Ombayega as the founder of the Datooga tribes connects tribes across geographical time and space into a traditional cultural collective of similar interests that "give rise to a distinct set of economic skills and values -at once material and ethical" (Salleh, 2009, p. 6). The recounting of stories of shared historical roots amongst the tribes promotes the collective regeneration of social networks and the preservation of epistemological knowledges from generation to generation. In 
addition, within these stories we witness the traditional ethos and epistemology of the Barabaig in which they maintain what Ariel Salleh (2009) refers to as a sustainable "metabolic fit" in the way that they "take from nature, digest, and give back in return" without depleting their ecosystem (p. 5-6). The Barabaig are geopolitically positioned at "the humanity-nature interface, taking care of biological flows, catalyzing matter/energy cycles" (Salleh, 2009 p. 17). By practicing transhumance moving based on "forage conditions and water availability" and a seasonal deferment system of grazing, they are able to maintain subsistence livelihoods (Lane, 1990, p. 82).

Originally, the Barabaig adapted to the conditions of their landscape by living nomadic lives and migrating with their cattle to perennial streams on the slopes of mount Hanang and to the volcanic lakes in the Bosuto plains. This seasonal deferment system of grazing was based on rainwater surface collection with rainfall averaging around $600 \mathrm{~mm}$ per year during the months of April/May and November/December. Because of the complicated tripartite system of land holding rights, cattle grazing did not lead to the depletion of resources. ${ }^{\text {vi }}$ In this conservative land use system, the community controls the overall landscape and topographical features, including sacred trees, Mount Hanang Forest, and all water sources, while the clans themselves control farmland, grave sites, water wells, and any abandoned bomas. Individual patriarchal heads of households own their homesteads and the areas surrounding them, including its trees and flora fauna. Barabaig livelihoods achieve the maximum "goal of balancing economic provisioning with intergenerational sustainability" (Salleh, 2009, p. 11). Yet, while the Barabaig continue to survive, their subsistence livelihood is not to be romanticized.

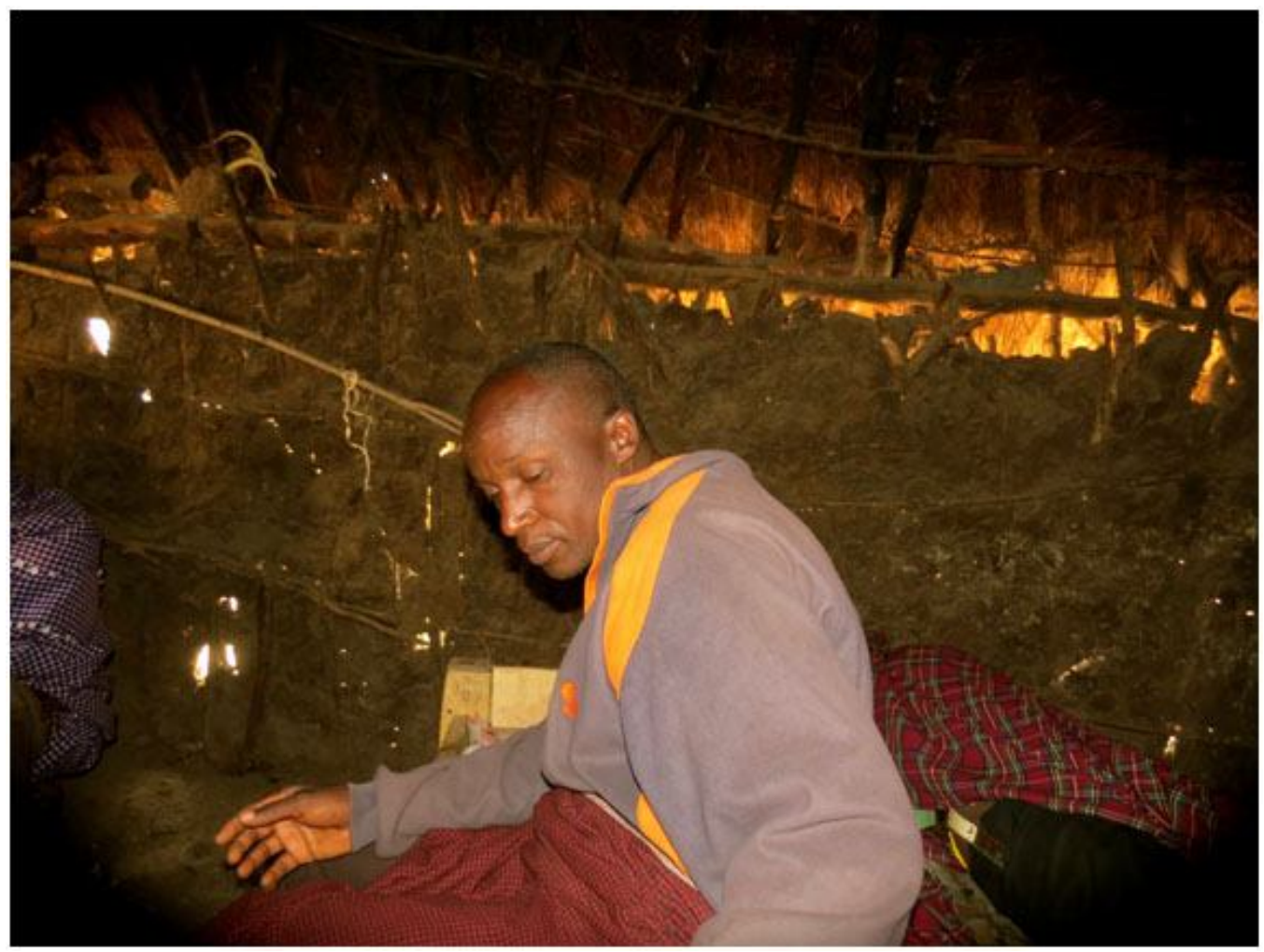

Figure 4. Chief Daniel in his boma telling the creation tale of the Barabaig

In the Barabaig world, women face "the heavy burden of labor" and "bear the brunt of responsibility," for not only traditional domestic responsibilities, including child-care, walking two hour distances for water collecting, food acquisition and preparation, but other agricultural 
tasks including wood collection and environmental management (Eriksen, Brown, \& Kelly, 2005). Men, on the other hand, have more freedom to move and access resources as they are not tied down to domestic responsibilities and can move with the cattle. The daily workload of Barabaig is onerous and from a Western perspective, perhaps, invokes Zora Neale Hurston's (1937) poignant observation that "De nigger woman is de mule uh de world so fur as Ah can see" (p. 14). On one of the four hour round-trips from the homestead to the waterhole, most of the women had to carry the water jugs weighing fifty plus pounds on their heads, without the use of the mule/donkey. Indeed the mule characterizes Barabaig women's precarious condition: "worked tuh death," "ruint wid mistreatment," yet strong enough to carry impossible "loads" nobody else wants to "tote" (Hurston, 1936, p. 56). Yet, in my interactions with the women, not one woman complained. ${ }^{\text {vii }}$ Barabaig women without kinship support because of divorce or widowhood face an even more heightened sense of vulnerability. In addition, gendered restrictions on mobility and access to labor, capital, natural resources have precluded Barabaig women from successfully implementing principal coping strategies.

It is not a surprise then that women's reproductive reality is narrated with little idealization as witnessed in this oral song that is sung by mothers to each other and to their female children. As Mama Paulina explains, the songs remind their children that "mama has suffered a lot" and that pregnancy and childbirth are wrought with pain and suffering (Cappelli, 2014). In Mama Paulina's words:

The problems and even sickness and whatever the mother passed through they must remind their children, but the stories turn into songs so they can be a time of happiness but it is a reminder for the children. And those children who have forgotten can remember mama's suffering from the song. (Cappelli, 2014)

She insists that: “The problem of pregnancy baba (father) doesn't know. We know ourselves. Mamas prepare these songs during pregnancy. They take the whole story based on their pregnancy experience" (Cappelli, 2014). Like the Tribals of Pirtha, the Mamas capture the "past in their songs," reflecting a strong sense of feminine authority about their reproductive experiences (Devi, 1995 p. 119).

The following is the song recorded on August 7, 2013.

Haya haya maleshi Goyewda.

Oh Oh Maleshi is Crying.

E semboda Dumda Etu Rukne Hawega.

This song I learned and is Sung by Girls.

Ooh Gebursa yenu Gidetu Seygeda.

Oh Will you tell me where I was seated? You will enable our generation to continue.

Oo Ghemata Bursa Gidahalegheda.

The Mother is tired and the Whole House we're Afraid.

Ooh Gomasew nagheda.

She is Going to Give a Gift.

Oo se Gidaganng'wenda asew nengheda.

Ooh birth is difficult, but it is the way for our generation to grow.

Oo mwalasi Gidabiw Hawega Lemshedi.

Oh, even clever girls will not escape the pain of childbirth.

Aaha Gidabiw halateda rayda Mushati.

No matter how beautiful I am, I must discard everything.

Aah Gwatimban ne ghwadah hagireda. 
Although, I am hallucinating and seeing hard times.

Oo Gawnen ghemata sida Risha.

Let you (my child) be the child of mother who can nourish you.

Haya haya maleshi Goyewda.

Oh Oh Maleshi is Crying. (Cappelli, 2014).

In this song, "reproductive consciousness is culturally transmitted," as mothers teach their children of the difficult processes of childbirth in which a mother must suffer and "discard everything" to give birth (O'Brien, p. 1983, p. 50). No matter what position a woman is in, once pregnant she cannot escape the pain of childbirth. The acknowledgement of the "seeing of hard times," coupled with the essentialist performativity as a song "only sung by girls" reinforces the gendered roles of young girls whose primary responsibility is to bear children, suggesting a “reproductive, genderic aspect consciousness" (O’Brien, 1983, p. 15).

The chorus "Maleshi is crying" acts as collective participation that childbirth affords-as all girl infants cry at birth at the pain they will knowingly suffer as mothers. Still, it is a necessary pain that reproduces continuity over time, the birth and growth of the next generation as well as the tribal need for regeneration. In an appeal to ethos, mothers are tasked to bear the gestational weight of their physical suffering by first considering the welfare of their offspring and tribal community before their own personal needs. The song suggests that the reproductive demands of the female body can never surpass the procreative component.

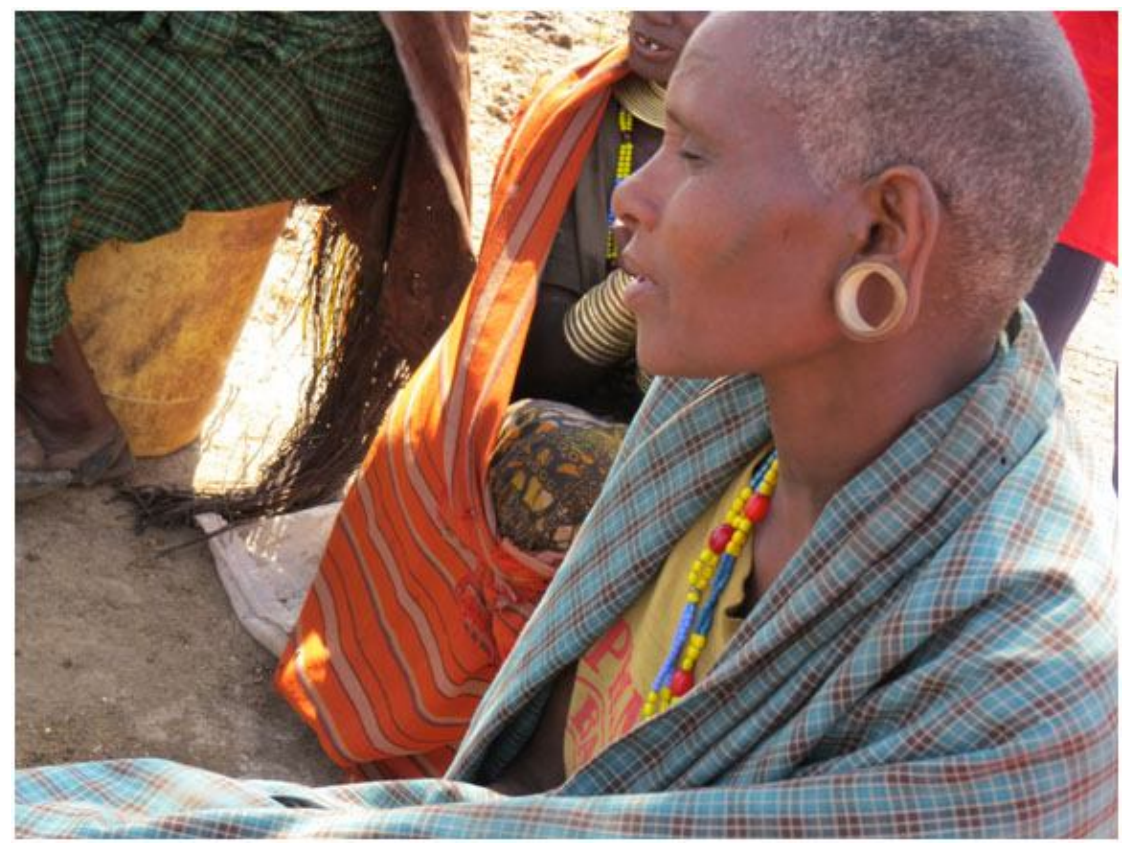

Figure 5. Mother giving advice to her daughter

Haya haya maleshi Goyewda suggests how traditional signs of female potency and lived experiences contribute to this awareness. Mama Paulina explains the song this way, "We have traditions. The thing they know is that when the child is born she will be raised to know all the things about the community about life and to be the person who is trusted in the community. Because it is a shame if the child is not trusted." The stories and songs create a shared history to legitimize gender constructions in an appeal to tradition and cultural survival. Paulina asserts that "before going to sleep we teach what is good and bad and what people need in the community. 
The story which is how to live in the community in peace, to obey to respect and protect what the community doesn't want and do what the community can do to live in peace."

These songs confirm O'Brien's (1983) observation, that "the dialectical structure of reproductive consciousness is reaffirmed in the social relations of reproduction, and thus in female consciousness"(p. 6o). Collectively, the mothers agree that the song and others not mentioned here transmit values, mores, customs, and traditions in order to teach young girls how to live and be a Barabaig: "The value which is produced by reproductive labor might be called 'synthetic' value. It represents the unity of sentient beings with natural process and the integrity of the continuity of the race" (O’Brien, 1983, p. 6o).

The protection of women's "synthetic value" during gestation is established in a set of agreed upon concepts and postulates concerning their rights to be safeguarded from the afflictions of bodily harm from their husband. According to the mothers, some of these offenses reported by Klima are still punishable by the tribal courts. Sanctions against these offenses are called ghordyod gademg or the fine of the women. The following offenses testify to the specificity of violent reproductive abuse some Barabaig women have encountered during their childbearing years. A man may be punished for the following:

1. If a husband kicks his wife's cooking stones, his action implies a wish for her death.

2. If a husband beats his wife after she returns from a werwerik, a neighborhood mission of sympathy for a woman who has just given birth.

3. If the midwife hears the husband beating another wife during the time when his pregnant wife is about to give birth.

4. If a husband beats his wife during her one-month convalescence after childbirth, the period called ghereg.

5. If the husband hits his wife over the head with a stick.

6. If the husband takes away his wife's clothes and sends her away from the homestead in a naked condition. (Klima, 1964, p. 90)

Upon looking at these reproductive specific offenses, we are faced with the cruel fact that women have suffered and continue to suffer sexual violence across geo-historical spaces prior to capital infiltration and other acculturating forces. Maria Mies links (1998) patriarchal violence in pastoral societies to "a one-sided relationship of exploitation and predation" (Mies, Thomson, \& Werlhof, p. 8). She attributes the inequality of gender relations in pastoral economies as a result of: "the monopoly of men over arms and the long observation of the reproductive behaviours of animals. As men began to manipulate the reproductive behavior of animals, they may have discovered their own generative functions" (Mies, Thomson, \& Werlhof , 1998, p.84). In the discovery of these "generative functions," men acted on their entitlement appropriating women's fertility and controlling bodies (Mies, Thomson, \&Werlhof, 1998, p. 84). 




Figure 6. Mothers convene under Baobob tree to discuss tribal issues

The adjudications of these offenses are held in a collective council of women under the central shade tree in which they convene a "moot" to decide the severity of the situation. ${ }^{\text {vii }}$ The idea that an individual reproductive offense against a pregnant woman is a collective offense against all women's reproductive systems proves the retributive and redistributive power Barabaig women hold within the clan. If a man is found guilty of a crime against reproduction, women secure jural remedies through the imposition of cattle fines. The remedy of cattle compensation for an offense is an economic deprivation against a man's property and resources and one of the most injurious charges against his livelihood. It is for this reason, Barabaig men often say: "They (the women) are going to 'eat' (consume) cattle needlessly" (Klima, 1964, p. 89). While a husband may be present at the council to defend or challenge the allegations of beating his pregnant wife with a stick or stripping her of her clothes and belongings, many times they do not attend in fear of risking the rage and retaliation of the collective council. Mediated by elder women, the proceedings are timeconsuming, as friends, family, neighbors-all have the opportunity to speak. If a man is found guilty as charged, in addition to incurring the expense of cattle, he must also submit a young black bull to bare the wrath of the women's rage. As a form of retaliatory retributive justice, women arm themselves with sticks and literally beat the young bull to death, sending a symbolic message to the abusive men of the clan. Beating the symbolic male replacement to a pulp is a visual admonition to all offenders, representing the true sentiments of the women (Klima, 1964, p. 91).

In order to verse their daughters in the ways of Barabaig life, mothers also give didactic advice as a way to synthesize and mediate reproductive labor. In Advice to our Daughters recorded on August 7, 2013, we witness the suggested day-to-day activities, which girls must perform to contribute to the domestic survival of their family units. Similar to India's tribals, " $\{t\}$ here is no "family planning in a poor area. A poor household needs many children" (Devi, 1985, p. 139). The advice is couched in responsibility-responsibility to the mother, to the community, to the land, and to the commitment to tribal continuity. "One goes to fetch wood, one pastures the goats of 
the village... one brings water, one goes to market to sell firewood" (Devi, 1985, p. 139). Taken as a whole the advice offers an economic model of cultural sustainability in which living needs are met. Advice to our Daughters include the following admonitions:

1. Sisina Mureda Gwenu e Gemadu.

Respect me and your Baba and his mama.

2. Gisisi Mureda Ng'ashega erukni Ghutenyu.

Respect all my words and what I command you to do.

3. Nala Gideba Gewaschi Gemadu.

Know that I am your mom.

4. Huwa wetenya.

Be our help.

5. $\quad$ Huwa sida weta be Fughara aba jeda Emeda.

Be the wisdom of the tribe.

6. Bwarinya Fukhaheng'wa e ghwa.

Love your community and your parents.

7. Adilehadi ne aduwi gelga sina gadiyeda ghaheng'wa.

Don't go to another's homes. Stay at your home and do your duties.

8. Jepta Huda ge ghwanal gew ng'ashega sin ghamwat aba Ghwa.

The baby and girl must learn to do everything she does in their home.

9. Una laja Ghwenga.

She must go to collect wood.

10. Sina E ghwadang'u.

She must make leather.

11. Sina Hang'wekagu.

She must make her own clothes.

12. Nala giwoschoda.

She must know how to cook well.

13. Weda ne Gidaw buneda Hamita.

She must help and give the people food.

14. Ramwa bega.

She must fetch the water.

15. Ghawa Dugwa ne Gisajischi.

She must milk cow and make milk and butter.

16. Iyeriti Ghana daruda guhuwi ghemata ghwanal Buneda gidebwa gendewi jepta hawega abwa ghwa.

When I leave the house you, daughter, must be the mother so that the people they know that I have you in this house.

17. Fura halenjeda I mendani ghwa.

Protect my property if I am not at home.

18. Imida gida gasa sida abwa ghwa imendani hiji, adidawi midang'u Denya, geghus ebalola seni. Adidaydi midang'u.

If there is anything that someone wants from our home, don't give it. It is not yours. It is ours. We have to sit down together and discuss. It is not yours to give.

19. Isighi Huda gagasa gawa gang'la ghenyi.

If a girl marries she must go and take care of husband and house.

20. Inya ne Gisni gida je gwargu siyedang'u. 
Accept and listen to whatever husband tells you to do.

21. I muy sida ghenyi gibigu ghwa gajeng'uley ne (Gergwech).

If husband is abusive, girl can return and family will take care of you.

22.

Bwarinya fukhaheng'a e Buneda sen be Datooga

Love your community, your people.

23. Heche una sen afkada ghaheng'wa (Ghwa).

Wherever you go remember your home. (Cappelli, o7 Sept. 2013).

Advice to our Daughters details the sexual asymmetrical division of labor and testifies to how a daughter's reproductive labor is an affective source of intrinsic use value that inheres in her physical potentiality, obedience, and industriousness. Women's affective labor is the center of production and reproduction. From producing the laborer-being and the ongoing processes of feeding, clothing, collecting water, hauling wood, and other myriad domestic chores, mothers and daughters are "vital producers." capital through which the "survival needs" are guaranteed (p. 206). The advice is characterized by ritual, respect, and responsibility embedded in a material complexity. Women invest traditional instruction and lessons in the sustainability of family units in their advice to their daughters. Their discourses are daily reminders of cultural expectations, the aim of which is simply the fortitude and determination of their Barabaig ways of existence in opposition to the external processes of national acculturation.

More importantly, Advice to our Daughters reveals a model of tribal subsistence production in which, "in the last analysis" is fueled by "female producers" (Mies, Thomson, \& Werlhof, 1998, p. 91).

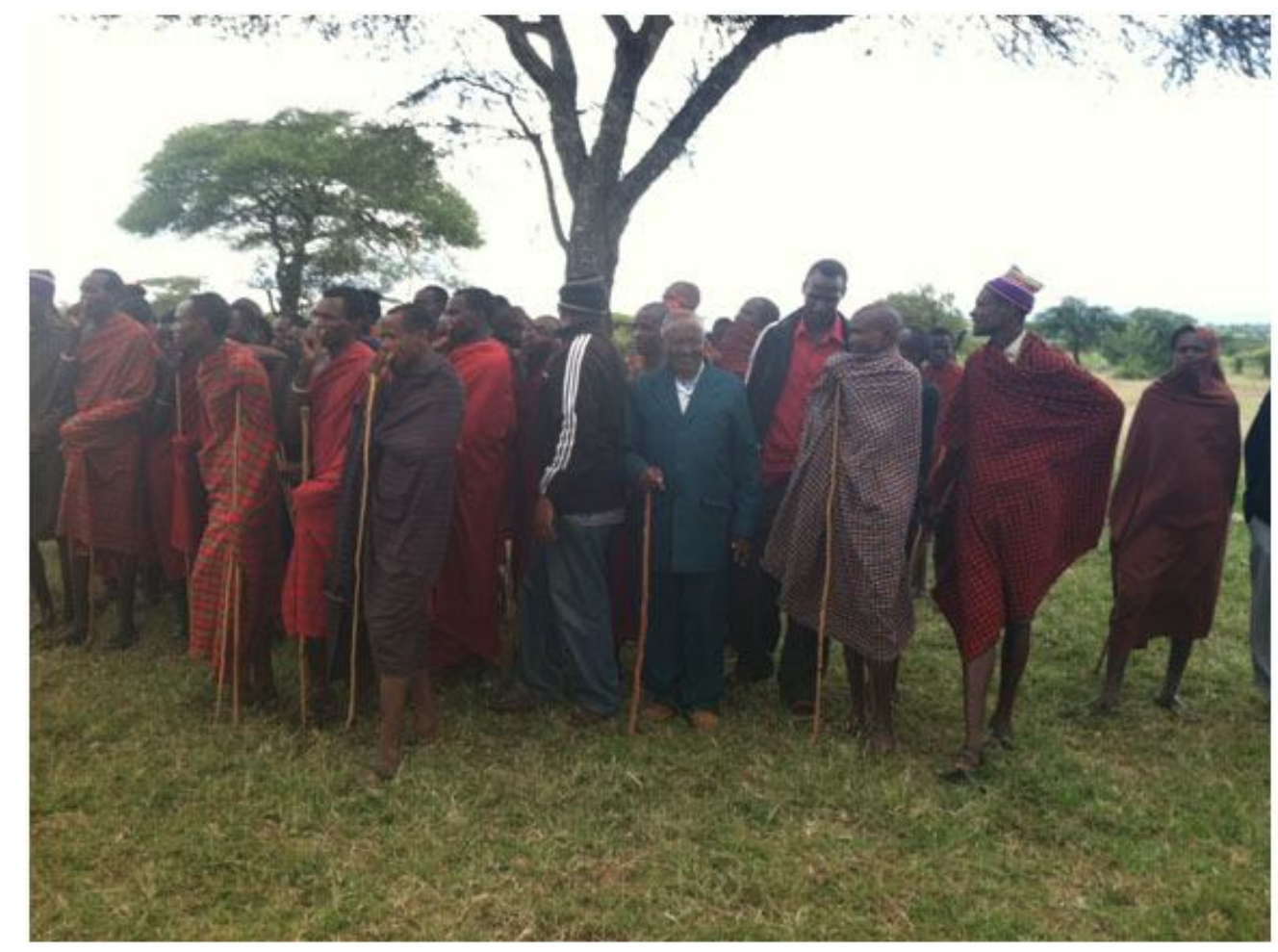

Figure 7. Barabaig Men

\section{Final Thoughts}


What has become clear is that Klima's 1955/56 assessment that the Barabaig are "present-time oriented" does not hold true for our $\mathbf{2 5}$ women who actively seek a survival strategy to live for their future tomorrows. Ideological notions claiming that "cultural flexibility is the key to survival" only furthers the ends of capitalism and globalization and the subjugation of indigenous native peoples (Klima, 1970). The Barabaig songs, mythohistories and advice provide insight into the historical realities, and, moreover, sustain and shape reproductive politics and women's reproductive decisions and productive livelihoods. The mythopoetic function of these discourses is vital to biopolitical production reinforcing an economic system capable of maintaining affective subjectivities and social networks of sustainability and cooperation.

Female reproductive contributions are what fuel and sustain past and present-day survival strategies amidst an ever-encroaching globalized world. Their cultural affects mold the ways Barabaig mothers make epistemological sense of their human existence. Moreover, these discourses provide cultural testimony as to how the traditional Barabaig epistemologies have created a powerful stronghold against Neo-Malthusian policies aimed at subaltern population control. Similar to the tribals of Mahasweta Devi's India, the Barabaig have constructed their own mythohistories to "bind the past to the present" in order to explain and understand "their nearly extinct sense of being" (Devi, 1985, p. 178). The Barabaig, like many tribal peoples left on earth, want "human recognition, respect, because he or she is the child of an ancient civilization" (Devi, 1985, p. 178).

Although we live in a world where connection to family, people, community, and place is no longer valued, the Barabaig have proven that sacred outposts of sustainable communities do still exist. They recognize the sacred interdependency and reverence of all life forms, and offer an urgent message on "how to construct a sense of sacred Nature which can help mobilize a general ecological mind-set beyond the reasonable and self-interested ground of long-term global survival" (Devi, 1995, p. 199). Their mythohistorical discourses offer a living testimony to examine indigenous resistance, social justice, and ecological sustainability.

On a personal note, as an ethnographer, I am aware that I came to visit the Barabaig with my "unshaken" faith in the power of "pen" and "paper" to record the stories of one of the few remaining indigenous peoples on the earth (Devi, 1995, p. 186). I'm also deeply mindful of the dubious nature of my presence in their lives as academics like me stumble upon them, and come and go. It is much more comfortable "safer to know life by reading books, reading theory" from a "parallel" distance (Devi, 1995, p. 158). Like Puran, my heart burst open with love for the Barabaig people, especially the twenty-five mothers I got to know. My heart confirms that "love, excruciating love," is the "first step" in understanding these beautiful beings (Devi, 1995, p. 196).

Our lives track on "parallel ways their world and our world our different," and to maintain cultural integrity, we must keep it this way (Devi, 1995, p. 195). When I asked Chief Daniel, what message he would like to share with the world, he responded:

"Please just let us be."

\section{Notes}

${ }^{\mathrm{i}}$ Fieldwork took place on three separate occasions between April 2011 and December 2014. 
ii In The Time of Sacred Places, Winona LaDuke observes the tragic irony of "settlers and intruders" determining native status and the bitterness many indigenous tribes feel towards this adjudication (88).

iii This is an alias name, so as not to cause any undue hardship to the mothers.

iv Three of the widows attempted to tell this myth, but they couldn't remember the full story, so they requested the Chief to narrate the story.

${ }^{v}$ Joshua Sumari helped with all the translations from Barabaig to English.

${ }^{v i}$ Garret Hardin's Tragedy of the Commons posits that overuse of the commons leads to environmental devastation.

vii On one water walk, Mama Happy was more concerned with why my 30-year old daughter did not have a husband or children.

viii The meeting place for most all communal discussions and moots is held under the central tree adjacent to the brick school building.

${ }^{\text {ix }}$ While recording the advice, a young six year old carrying a burdensome bundle of wood returned from completing one of her many chores of the day.

\section{References}

Adamson, J., Evans, M. \& Stein, R. (2002). The Environmental Justice Reader: Politics, Poetics, E Pedagogy. Tucson, Arizona: University of Arizona Press.

Bennholdt, Thomsen, V., Mies, M. \& von Werlhof, C. (1998). Women: The Last Colony. London, England: Zed Books.

Cappelli, M. (2012, June 22). Personal interview.

Cappelli, M. (2013, June 19) Personal interview.

Devi, M. (1994). Imaginary Maps. New York: Routledge. . (1990) Of Women, Outcasts, Peasants, and Rebels. (Kalpana Bardhan, Trans.) Berkeley, Calif: University of California

Eriksen, S, H., Brown, K. \& Kelly, M. (2005). "The Dynamics of Vulnerability: Locating Coping Strategies in Kenya and Tanzania." The Geographical Journal 171(4), 287-305.

Hawthorne, S. (2009). The Diversity Matrix: Relationship and Complexity. In Salleh, A. (Ed.), EcoSufficiency \& Global Justice: Women Write Political Ecology. North Melbourne, Australia: Spinifex Press.

Hennessy, R., \& Ingraham, C. (1997). Materialist Feminism: A Reader in Class, Difference, and Women's Lives. New York, NY: Routledge.

Hurston, Z. N. Their Eyes Were Watching God. (1937). New York, NY: J.B. Lippincott.

Klima, G. (1964). Jural Relations between the Sexes among the Barabaig. Africa 34 (1), 9-20. (1985). The Barabaig East African Cattle Herders. New York, NY: Waveland Press.

Kupperman, J. S. (2010). Myth, History and Mytho-History: An Essay. Journal of the Western Mystery Tradition 19 (2).

Lane, R. C. (1990). Barabaig Natural Resource Management: Sustainable Land use under Threat of Destruction. United Nations Research Institute for Social Development Discussion, Discussion Paper, No 12 . 
.(1994). Pastures Lost: alienation of Barabaig Land in the context of Land Policy and Legislation in Tanzania. Nomadic Peoples, 34 (35) 81-94.

O'Brien, M. (1983). The Politics of Reproduction. London, England: Unwin Hyman.

Maathai, W. (2007). Unbowed: A Memoir. New York, NY: Alfred A. Knopf.

Merchant. C. (2005). Radial Ecology: The Search for a Livable World. New York, NY: Routledge.

Minh-ha, Trinh T. (2009). Woman, Native, Other: Writing Postcoloniality and Feminism. Bloomington, Indiana: Indiana UP.

Peter, C. M. (2007). Human Rights of Indigenous Minorities in Tanzania and the Courts of Law. International Journal on Minority and Group Rights, 14 (4).

Salleh, A. (2009). Ecological Debt: Embodied Debt. In Salleh, A. (Ed.), Eco-Sufficiency E Global Justice: Women Write Political Ecology. North Melbourne, Australia: Spinifex Press.

Shivji, I. G. (2007). State Coercion and Freedom in Tanzania. Journal of Group and Minority Rights.

Shiva, V. (2005). Earth Democracy. Justice, Sustainability, and Peace. Cambridge, London: South End Press, 2005 . (2010). Staying Alive: Women, Ecology, and Development. Cambridge, England: South End Press.

Smith, L.T. (1999). Decolonizing Methodologies: Research and Indigenous Peoples London, England: Zed Press.

Vaughan-Lee, L., et. al. (2013). Spiritual Ecology: The Cry of the Earth. Point Reyes, California: Golden Sufi Center. 